\title{
Pencarian Makna Hidup Siswa dari Keluarga Miskin di Kabupaten Wonosobo
}

\author{
Musofa $^{1}$, Casmini ${ }^{2}$, Sutrisno $^{3}$ \\ Program Doktor Universitas Islam Negeri Sunan Kalijaga, Yogyakarta, Indonesia ${ }^{1}$ \\ Fakultas Dakwah dan Komunikasi, Universitas Islam Negeri Sunan Kalijaga, Yogyakarta, Indonesia ${ }^{2,3}$ \\ e-mail: casminiuin@gmail.com ${ }^{2}$
}

\begin{abstract}
Students from poor families seems to have the ability to search the meaning of life. They have high enthusiasm in education. This study aims to explore the reasons of poor students in searching for life's meaning by choosing high school, concepts of meaning in life, and learning and its implications. The study used phenomenological-qualitative method. The participants were 21 students from poor families in reputable high school in Wonosobo. Data was collected through interviews and focus group discussion and was analyzed inductively. The results show that students from poor families understand the possibilities and benefits of achieving goals to be success in the future. Student balance is indicated by the determination of high goals and the hard work done in material, psychological and spiritual aspects. They are confident to move on and reflect the life's meaning by act and pray.
\end{abstract}

Keywords: meaning of life, ambitions, value of success, parents, tiered goals

\begin{abstract}
Abstrak
Siswa dari keluarga miskin menunjukkan kemampuan pencarian makna hidup. Mereka tetap mampu bertahan dan memiliki semangat yang tinggi dalam menempuh pendidikan dengan berbagai keterbatasan ekonomi. Penelitian ini bertujuan untuk mengungkap alasan siswa miskin dalam melakukan pencarian makna hidup dengan memilih SMA favorit, konsep-konsep makna hidup, serta pembelajaran dan implikasinya. Penelitian bersifat kualitatif-fenomenologis dengan partisipan 21 siswa keluarga miskin dari SMA terfavorit di Kabupaten Wonosobo. Data dikumpulkan melalui wawancara dan focus group discussion yang dianalisis secara induktif. Hasil penelitian menunjukkan bahwa siswa dari keluarga miskin memahami kemungkinan dan manfaat pencapaian tujuan yang dijalani secara bertahap menuju ke arah pencapaian yang lebih tinggi sebagai nilai keberhasilan yang ingin diulang di masa depan. Keseimbangan siswa ditunjukkan dengan penetapan cita-cita yang tinggi dan upaya keras yang dilakukan dalam aspek material, psikologis dan spiritual. Mereka percaya diri untuk melangkah dan memaknai setiap yang diupayakan dengan usaha dan doa.
\end{abstract}

Kata Kunci: makna hidup, cita-cita, nilai keberhasilan, orang tua, tujuan berjenjang

\section{Pendahuluan}

Tekanan ekonomi bagi siswa miskin berhubungan dengan distress psikologis (O'Neal, Arnold, Lucier-Greer, \& Wickrama, 2015) dan disfungsi sosial yang berbeda pada kelompok miskin dan sangat miskin dengan kelompok kurang miskin (Liputo, 2014) dan menimbulkan berbagai perilaku anti sosial (Berti \& Pivetti, 2017) serta mengakibatkan depresi (Noviawati \& Narendri, 2017). Kondisi kemiskinan bagi siswa, berdampak pada pendidikan rendah (Rashid \& Samat, 2018) dan bekerja tanpa keterampilan memadai (Cheung \& Chou, 2016), bekerja dengan gaji rendah (Sasmal \& Guillen, 2015) dan menyebabkan munculnya keluarga miskin generasi baru serta berimplikasi pada kemakmuran individu dan masyarakat (Woessmann, 2015). Langkah yang bisa dilakukan untuk memutus mata rantai kondisi psikologis siswa miskin adalah pendidikan yang 
bermutu (Crarke \& Feeny, 2007), meskipun cukup sulit realisasinya (Martono, 2017).

Hasil penelitian pendahuluan dengan angket yang disebarkan kepada 21 siswa dari SMA Negeri 1 Wonosobo dan SMA Negeri 2 Wonosobo terdapat realitas berbeda, yaitu mereka mampu menentukan pilihan hidup dengan memilih SMA favorit dan bertekad melanjutkan pendidikannya ke perguruan tinggi. Kekurangan biaya hidup bukan menjadi kendala, namun menjadi stimulasi yang mendorong siswa dari keluarga miskin untuk mendapatkan beasiswa, pengakuan sosial, menatap masa depan untuk melanjutkan ke perguruan tinggi dan pencarian makna hidup. Kekuatan mental siswa dari keluarga miskin mampu mengikis kemiskinan (proper), ketidakberdayaan (powerless), kerentanan menghadapi situasi darurat (state of emergency), dan ketergantungan (dependence), meskipun Angka Partisipasi Kasar (APK) Pendidikan Tinggi yang baru mencapai 28.10\% (Nasir, 2016).

Fenomena siswa miskin di Wonosobo menunjukkan adanya kondisi psikologis khusus yang memungkinkan mampu melawan kondisi penuh tantangan dan kesulitan dalam situasi dan kondisi miskin. Realitas psikologis ini tentu menjadi menarik untuk dikaji lebih mendalam terkait dengan makna hidup. Makna hidup dalam situasi kemiskinan bukanlah hal yang mustahil. Makna hidup dapat membawa seseorang menerima keadaan kekurangan, dibuktikan bahwa terdapat korelasi .402 dan signifikansi $\mathrm{p}=.001$ $(\mathrm{p}<.05)$, yang menunjukkan bahwa terdapat hubungan yang positif antara kebermaknaan hidup dengan peneriman diri (Sari \& Purwaningsih, 2012), dan berkaitan dengan antusiasme mengenai masa depan (George \& Park, 2013).

Makna hidup tidak diraih ketika berada pada usia dewasa (Erikson dalam Fridayanti, 2013), namun menjadi bagian dari taraf perkembangan integritas yang akan dicapai pada masa dewasa dan dilakukan pencarian pada usia remaja. Usia dewasa awal memiliki perasaan positif lebih besar yaitu $62 \%$ dibandingkan dengan remaja maupun dewasa madya (Noviawati \& Undarwati, 2017). Penderitaan remaja tidak menghalangi untuk pencarian makna dalam hidup. Peristiwa putus sekolah merupakan tahapan dalam menapaki tahap derita, tahap kesadaran diri, tahap penerimaan diri, tahap realisasi makna dan tahap mencapai makna hidup (Purwanda, 2015). Semua kegiatan dan peristiwa yang dihadapi dalam kehidupan memiliki arti dan menjadi kesadaran untuk pencarian makna (Mustea, 2012; Fridayanti, 2013) sehingga mencapai kesuksesan (Ratcliffe, 2015).

Kesuksesan diawali dari konsep makna hidup yang sedang diupayakan oleh siswa miskin untuk dapat berubah dari kemiskinannya yang merupakan proses dari kehidupan untuk menemukan makna sehingga mendapatkan hidup bermakna (the meaningful life) atau gagal menemukan makna sehingga hidupnya tanpa makna (Bastaman, 2007). Tindakan hanya akan bermakna sejauh pemilihannya dibuat dari rangkaian kemungkinan tindakan, maka sebelum perubahan kemiskinan itu terjadi ada makna-makna hidup lain yang mendahului (Luhmann dalam Rizte, 2014).

Makna hidup adalah hal-hal yang dianggap sangat penting, benar, berharga serta memberikan nilai khusus bagi seseorang, sehingga layak dijadikan tujuan dalam kehidupan (Bastaman, 2007). Makna hidup merupakan kebutuhan (the need for meaning) meliputi need for purpose, need for value, need efficacy dan need for self worth (Baumeister dalam Fridayanti, 2013) dan mencakup dimensi pemahaman komprehensif (kognisi), tujuan dan nilai (Martela \& Steger, 2016). Makna hidup muncul dari hubungan antara interpretasi, aspirasi, dan evaluasi yang membuat pemahaman, upaya menuju, dan rasa penting (Steger, 2012).

Penelitian ini bertujuan untuk mengungkap alasan siswa miskin dalam 
melakukan pencarian makna hidup dengan memilih SMA favorit, konsep-konsep makna hidup, serta pembelajaran dan implikasi personal maupun sosial yang berkaitan dengan makna hidup. Pencarian makna hidup diawali dari respon terhadap situasi kemiskinan dan minat sekolah, perubahan dimensi koherensi pemahaman, penetapan dan pencapaian tujuan, kemudian perasaan nilai.

\section{Metode Penelitian}

Penelitian ini bersifat kualitatiffenomenologis dengan subjek 21 siswa dari keluarga miskin yang penghasilan orang tuanya tidak mencukupi biaya pendidikan sekolah di SMA terfavorit di Kabupaten Wonosobo. Subjek terdiri dari 18 siswa SMA Negeri 1 Wonosobo dan 3 siswa SMA Negeri 2 Wonosobo. Data tentang makna hidup digali dari siswa dengan wawancara mendalam, tanya jawab tertulis dan focus group discussion (FGD). Pengembangan instrumen penggalian data didasarkan atas tiga dimensi makna hidup dengan indikator yang telah ditetapkan, meliputi dimensi pemahaman mengenai pengalaman hidup (koherensi), dimensi sasaran atau tujuan dan dimensi nilai yaitu perasaan atau anggapan nilai makna dalam hidup (signifikansi).

Proses wawancara, tanya jawab dan FGD dilakukan langsung oleh peneliti, dengan memperhatikan kenyamanan tempat wawancara, durasi waktu, dan kejenuhan siswa. Hasil wawancara dan FGD disimpan dengan alat perekam, kemudian dituliskan dalam transkrip wawancara.

Data yang telah tertata dibaca secara menyeluruh dari ungkapan 21 subjek untuk ditangkap gagasan inti dari setiap transkrip, dipilih data menarik dan penting kemudian dipelajari lebih lanjut untuk mengetahui makna dasar data, membuat catatan gagasan ke kalimat faktual dan menuliskan topik. Meskipun disediakan panduan wawancara, peneliti tidak mengarahkan jawaban informan maka tidak selalu menghasilkan topik berkelompok, oleh karena itu dilakukan pengelompokan topik, mengkode topik utama, dan kode khusus.

Temuan hasil wawancara dan FGD dari 21 subjek memiliki kemiripan narasi meski diungkapkan dengan gaya bahasa yang berbeda, maka paparan hasil penelitian dideskripsikan dari temuan tema pada keseluruhan subjek penelitian. Temuan data dibuat menjadi kategori topiktopik serta menganalis hubungan antar topik, selanjutnya menyusun deskripsi untuk menggambarkan makna hidup subjek dengan melakukan analisis data secara induktif.

\section{Hasil Penelitian dan Pembahasan}

\section{Hasil Penelitian}

Semua subjek menyatakan bahwa pada dasarnya kehidupan itu mempunyai orientasi dan tujuan meskipun dirinya dari keluarga miskin. Subjek HR, ZM, VAP menyatakan bahwa "Hidup harus memiliki tujuan", INK: "Mewujudkan mimpi-mimpi atau tujuan" dan "Dapat mengikuti norma etika", INS: "Mengubah yang tidak baik menjadi lebih baik", MAE: "Menerima segala kelebihan dan kekurangan", SFI, INS: "Dikenang sepanjang waktu", UK: "Mmasalah bukan lari dari masalah", YFA: "Menginspirasi orang lain", VAP: "Menyukai yang dialami", ZM: "Dapat mengendalikan jalan hidup meskipun sudah ada takdir".

Hidup harus membawa kebermanfaatan seperti yang diungkapkan subjek SFI, sebagai berikut:

"Hidup bermakna adalah selama kita masih hidup dapat bermanfaat bagi orang lain, dapat membantu mengurangi beban orang lain, dapat menjadi hal yang dapat dikenang dan diingat sepanjang waktu meski raga telah terkubur bumi, akan lebih bermakna apabila apa yang pernah kita lakukan dapat bermanfaat untuk orang banyak apalagi untuk orang yang lebih kecil dari kita".

Subjek VAP menyatakan bahwa: 
"Yang bermakna adalah hidup yang begitu penting, ada tujuan untuk melangkah ke depannya serta diri ini merasa nyaman, bahagia, serta melakukan itu dapat menghasilkan yang terbaik untuk nantinya. Bukan hidup yang hanya berfoya-foya tanpa tujuan hidup itu akan kemana. Hidup yang bermakna juga hidup yang bagaimana kita mensyukuri atas apa yang kita lewati. Entah itu dalam situasi tidak punya tetapi kita tetap merasakan kebahagiaan yang sejati. Hanya dengan bersyukur kita dapat memaknai setiap langkah bahkan liku dalam kehidupan dan masalah bukanlah menjadi beban tetapi masalah adalah warna pelengkap dalam hidup. Hidup yang bermakna adalah hidup yang memiliki tujuan. Hidup yang digunakan untuk menempuh tujuan hidup. Hidup yang digunakan untuk melakukan hal-hal yang bermanfaat. Hidup yang bermakna adalah hidup dimana kita menikmati setiap kegiatan yang kita lakukan. Hidup tidak akan bermakna kalau kita tidak menikmati dan meresapi setiap hal yang kita lakukan. Hidup yang bermakna adalah dimana saat kita memiliki orang-orang yang selalu ada bersama kita. Hidup yang tidak dipenuhi dengan kesepian. Hidup yang dipenuhi dengan apa yang kita butuhkan. Hidup yang bermakna itu jika kita bisa mengendalikan jalan hidup kita walau sudah diatur oleh takdir, pada intinya hidup akan bermakna kalau kita mengerti, memahami, dan menikmati arti dari hidup".

Semua subjek menyatakan bahwa pemilihan dan diterimanya di sekolah favorit dengan beasiswa saat ini merupakan awal dari proses kepada kehidupan yang lebih baik. Kendala biaya bukan sebagai hambatan untuk nantinya melanjutkan kuliah ke perguruan tinggi. Mereka telah memikirkan apa yang akan dilakukan jika orang tuanya tidak sanggup membiayai. Hal tersebut dinyatakan kebanyakan siswa seperti kuliah sambil bekerja dan berusaha semaksimal mungkin mendapatkan beasiswa. Pikiran yang lebih realistis dari mereka adalah melakukan sesuatu dikala masih berstatus pelajar, sebagaimana yang dinyatakan subjek DN berikut ini:

"Berhubung sekarang saya masih sekolah, usaha yang bisa saya lakukan belajar dengan giat belajar, karena saya tidak les seperti teman-teman saya, maka saya harus bisa lebih semangat dari mereka. Dengan saya belajar, berdoa, saya yakin saya bisa mencapai hal yang saya ingin capai, saya bisa diterima di perguruan tinggi yang saya inginkan, setelah itu saya bisa bekerja menghasilkan uang, dan selanjutnya saya bisa membantu keluarga saya, khususnya di bidang ekonomi".

Subjek RDY lebih luas lagi dalam mengungkapkan tujuan hidupnya, yaitu:

"Tujuan hidup saya adalah bermanfaat bagi orang lain, sebagaimana dijelaskan dalam Alquran atau Hadis bahwa sebaik-baik manusia yang bermanfaat bagi sesamanya, saya ingin adanya saya dapat berpengaruh pada kehidupan orang-orang di sekitar saya, dan kehadiran saya bisa diakui oleh orangorang di sekitar saya. Namun, tujuan hidup saya sebenarnya adalah mencari keridhaan-Nya bahwa saya hidup di dunia hanyalah sementara, akan datang dimana kita akan meninggal dunia dan memasuki alam akhirat. Di dalam akhirat inilah kita akan mempertanggungjawabkan semua yang kita lakukan di dunia. Jadi saya akan senantiasa bertaqwa untuk mencari keridhaan-Nya".

Penerimaan terhadap keadaannya seperti yang diungkapkan INK berikut ini:

"Kondisi ini mungkin kondisi terbaik untuk keluarga saya. Mungkin jika saya tidak dilahirkan dengan kondisi demikian, saya tidak akan menjadi diri saya yang sekarang, yang penuh motivasi dan keinginan untuk maju. Mungkin dengan seperti ini saya menjadi orang yang lebih menghargai orang lain, menghargai orang tua dan kerja keras mereka, serta menghargai uang". 
Lebih berat lagi bagi INS yang terpaksa ikut kakek dan neneknya karena orang tuanya merantau dan ZM yang ayahnya meninggal dunia atau YFA yang orang tuanya mengalami kebangkrutan. Bagi INS, ZM dan INK, Allah telah merencanakan takdir dirinya dengan sebaik-baiknya. Berikut ungkapan INK:

"Rencana Allah menakdirkan orang tuanya yang memiliki kondisi ekonomi seperti yang ia rasakan menurutnya dimaksudkan agar tumbuh keinginan dalam diri saya untuk menyimpulkan kehidupan yang lebih baik dan terus berjuang dengan cara yang benar, tentunya rejeki, jodoh, dan maut tentu adalah takdir Allah. Rejeki orang tua saya berarti adalah takdir Allah dan saya akan berjuang untuk menjadikannya lebih baik”.

Ungkapan HS: "saya memahami semua akan kembali kepada Allah, sebisa mungkin melakukan apapun disandarkan dan dipasrahkan kepada Allah".

Kemiskinan keluarga bukan hal yang harus diratapi, tetapi dijalani dengan melalui sebuah proses secara bertahap. Sebagaimana ungkapan subjek UK dan ANM bahwa "Kehidupanku harus terus berjalan, harus kulalui dengan optimis dengan tanpa melepas nilai dan etika kehidupan". Tekad ini yang menjadikan ANM memperoleh prestasi, sebagaimana pernyataannya:

"Saya pernah menjuarai suatu lomba dan ada hadiahnya. Hadiah itu alhamdulilah jadi rizki yang berkah menjadi mata pencaharian orang tua saya sekarang. Mengingat pada waktu itu ekonomi keluarga benar-benar terpuruk".

\section{Pembahasan}

Pencarian makna hidup siswa dari keluarga miskin ditunjukkan melalui proses pemilihan Sekolah Menengah Atas (SMA) favorit. Pencarian makna hidup didasarkan atas adanya hasrat untuk bermakna (the will to meaning) yang mendorong dalam menemukan makna melalui tahapan remaja dan matang pada dewasa. Siswa sekolah menengah berupaya menyadari bahwa semua peristiwa yang dihadapi dalam kehidupan memiliki makna (Mustea, 2012) dalam dimensi yang memperhatikan need for meaning (Baumeister, 1991) dan the three meanings of meaning in life (Martela \& Steger, 2016) dengan penekanan koherensi, tujuan, dan nilai.

Pencarian makna hidup siswa dari keluarga miskin di Wonosobo pada keseluruhan subjek diawali dari respon terhadap situasi kemiskinan dengan pemilihan sekolah favorit yang relevan dengan minatnya (Fridayanti, 2013), meliputi dimensi koherensi, tujuan dan nilai. Koherensi sebagai rasa komprehensibilitas maka pemahaman subjek terhadap seluruh hal yang terkait dengan pilihan SMA-nya merupakan wujud makna sehingga semakin luas cakupan pemahaman yang saling terkait akan semakin menguatkan maknanya. Gambaran makna dimensi koherensi siswa ditunjukkan dalam tiga hal, pertama, pemahaman mengenai situasi dan kondisi keluarga yang dialami dalam hidup siswa. Kedua, pengetahuan hubungan pilihan SMA favorit dengan kondisi keluarga dan hal lainnya, dan ketiga, pemahaman mengenai adanya kesempatan dan adanya hal yang dapat dilakukan terkait pilihan SMA favorit.

Makna hidup yang terkait situasi dan kondisi adalah memahami pengalaman siswa dalam merespon lingkungan yang melekat dalam hidupnya. Pemahaman terhadap situasi dan kondisi siswa ditunjukkan dengan rasa memahami pekerjaan dan penghasilan orang tua serta kebutuhan keluarga. Mengenai pekerjaan tidak hanya jenisnya yang diketahui namun subjek mengetahui tempat, waktu, dan pendukungnya. Berkaitan dengan penghasilan, siswa mengetahui dari informasi yang diberikan orang tuanya terutama ketika mengisi data penghasilan orang tua. Demikian pula kebutuhan keluarga diketahui dari data isian siswa. Pemahaman tentang kekurangan biaya dan penyebab 
kesulitan keuangan keluarga diketahui melalui informasi perincian penghitungan biaya personal, biaya transportasi, makan, alat tulis, pakaian sekolah, dan biaya personal pendukung kegiatan sekolah. Pengalaman kekurangan uang ketika akan membayar sekolah menstimulasi upaya meraih beasiswa atau mendapatkan keringanan pendidikan di SMA.

Makna koherensi juga ditunjukkan dengan mengetahui adanya pola-pola hubungan sebab akibat dalam kehidupan (Heintzelman \& King, 2014). Pengetahuan mengenai hubungan pilihan SMA favorit dengan kondisi keluarga ditunjukkan dengan keberatan orang tuanya dengan cita-citanya melanjutkan pendidikan ke perguruan tinggi, serta ijin yang diberikan orang tuanya. Rendahnya tingkat pendidikan orang tua memberikan stimulasi yang kuat bagi dirinya untuk tetap sekolah dengan berupaya mendapatkan beasiswa. Upaya integrasi antara keinginan dirinya, mempertimbangkan saran orang tua dan memperhitungkan manfaat dan madharat menjadi bentuk koherensi yang dialami.

Makna dimensi koherensi memuat adanya pemahaman mengenai kesempatan dan banyak hal yang dapat dilakukan dalam menghadapi kesulitan hidupnya (Frankl dalam Bastaman, 1995). Pemahaman atas kesempatan dibuktikan dengan keberhasilan mendapatkan beasiswa atau keringanan pendidikan di SMA, keyakinan adanya peluang beasiswa pendidikan dan prestasi yang didasari oleh semangat untuk meringankan beban biaya orang tua. Pemahaman kesempatan diimbangi pula dengan upaya penghematan seperti menahan lapar tidak jajan, membawa bekal makanan ke sekolah serta menahan keinginan yang tidak terjangkau oleh dirinya.

Dimensi tujuan terkait dengan pilihan siswa miskin pada SMA favoritnya dan perencanaan untuk melanjutkan ke pendidikan tinggi yang selaras dengan tujuan sebagai penghubung antara kejadian masa kini dan masa yang akan datang
(Baumeister, 1991). Makna hidup dalam dimensi tujuan meliputi tujuan utama yang telah dan ingin dicapai berkaitan dengan pilihan SMA-nya (Baumeister, 1991), memiliki optimisme serta motivasi dalam mencapai tujuan inti (Steger, 2016) dan memiliki sikap dan tindakan terarah dalam mencapai tujuan inti, sebagaimana penelitian pada orang dengan social anxiety disorder (SAD) ketika mereka mencurahkan banyak usaha untuk mencapai tujuan dalam hidup, maka makna hidup meningkat (Kashdan \& McKnight, 2013).

Makna dalam tujuan utama yang telah dan ingin dicapai berkaitan dengan pilihan SMA-nya ditunjukkan oleh subjek dengan semangat untuk melanjutkan ke perguruan tinggi tanpa membebani orang tua, penetapan jurusan atau bidang pendidikan yang diinginkan di pendidikan tinggi dan telah memiliki gambaran pemanfaatannya. Pada SMA-nya saat ini memiliki sportivitas yang tinggi untuk mendapatkan nilai dan prestasi. Mereka berkeyakinan dapat meraih cita-cita melalui berkompetisi dengan sekolah lain yang termasuk favorit. Optimisme meraih SMA favorit melandasi pendidikan tinggi dan berkeyakinan dapat mengulang keberhasilan sebelumnya. Keberhasilan dapat mencapai SMA favorit mempengaruhi sikap optimisme siswa dalam mencapai tujuan inti.

Sikap dan tindakan yang terarah dalam mencapai tujuan inti direalisasikan dalam perilaku penghematan seperti membawa bekal makan, berpuasa, berjalan kaki ke sekolah, serta menahan keinginan pada halhal yang kurang penting. Tindakan terarah juga pada upaya mencari informasi persaingan pemilihan jurusan yang sama dalam satu sekolah, mencari informasi beasiswa pendidikan tinggi, menunjukkan rasa senang terhadap jurusan yang ingin dimasuki, berdoa agar dikabulkan keinginan masuk perguruan tinggi sesuai pilihannya. Sebagian siswa juga berpikir untuk mencari tambahan penghasilan agar bisa membantu orang tuanya. 
Dimensi signifikansi dalam makna hidup adalah perasaan dirinya berharga dan penting sebagai siswa karena nilai berkaitan dengan derajat penting, berharga atau sangat berharga (George \& Park, 2014). Bagi siswa, nilai berharga dan penting diungkapkan dengan perasaan bangga ketika mendapatkan sekolah favorit dan mendapatkan kejuaraan dalam salah satu perlombaan. Nilai positif terkait dengan perasaan dalam mendapatkan perlakuan dan pengakuan baik dari lingkungan yang layak untuk menjalani hidup dan kemampuan mengevaluasi kehidupan (Martela \& Steger, 2016). Nilai ideal dalam hidup bermakna ketika hidup lebih baik, berhasil dan bertanggung jawab, seperti merasa layak menjadi kakak kelas yang sukses dengan kemiripan latar belakang ekonomi keluarga, dan merasa dalam keadaan terbaik untuk meraih citacitanya.

Temuan makna hidup dalam tiga dimensi koherensi, tujuan dan nilai terikat oleh konteks kondisi kemiskinan keluarga siswa dan pilihannya pada SMA favorit. Pemenuhan makna hidup siswa menunjukkan perbedaan antar siswa, sebagaimana disajikan pada tabel 1 .
Tabel 1

Pemenuhan Makna Hidup Siswa

\begin{tabular}{|c|c|c|}
\hline $\begin{array}{l}\text { Nama } \\
\text { Inisal }\end{array}$ & $\begin{array}{c}\text { Cita-cita } \\
\text { pendidikan tinggi } \\
\text { atau profesi }\end{array}$ & Tempat \\
\hline INK & $\begin{array}{l}\text { Profesor and } \\
\text { Chemical } \\
\text { Engineer }\end{array}$ & Oxford University \\
\hline DNPP & Konsultan pajak & STAN \\
\hline ACS & $\begin{array}{l}\text { Profesor S3 di } \\
\text { luar negeri }\end{array}$ & $\begin{array}{l}\text { UGM/UNDIP/UI/ } \\
\text { ITB }\end{array}$ \\
\hline RFL & Akuntan & STAN Akuntansi \\
\hline SFI & $\begin{array}{l}\text { Dokter/ Guru/ } \\
\text { Sutradara }\end{array}$ & UGM \\
\hline YFA & Psikolog & UNDIP/UNNES \\
\hline INS & $\begin{array}{c}\text { Guru } \\
\text { SM3T/Penulis }\end{array}$ & UNS \\
\hline VAP & $\begin{array}{l}\text { Kedinasan, } \\
\text { Arsitek }\end{array}$ & ITB \\
\hline $\mathrm{ZM}$ & Pengamat Alam & UGM Kehutanan \\
\hline RFL & Teknisi/Dosen & ITB/UGM \\
\hline HR & $\begin{array}{l}\text { Ilmuwan } \\
\text { Konservasi } \\
\text { Kehutanan }\end{array}$ & IPB Kehutanan \\
\hline IN & Dosen & UI \\
\hline MAE & Pengusaha & Perguruan Tinggi \\
\hline $\mathrm{DN}$ & Banking & STAND \\
\hline GAP & Perwira TNI & AKMIL \\
\hline ANM & $\begin{array}{l}\text { Membahagiakan } \\
\text { keluarga }\end{array}$ & STIS \\
\hline UH & $\begin{array}{c}\text { Menteri } \\
\text { Pemberdayaan } \\
\text { Perempuan }\end{array}$ & UNY/UNNES \\
\hline VI & $\begin{array}{l}\text { Guru/Polisi/ } \\
\text { Aktivis }\end{array}$ & $\begin{array}{l}\text { UNDIP/UGM/ } \\
\text { STKS/UNS }\end{array}$ \\
\hline
\end{tabular}


Makna dalam pengertian tujuan hidup tersistem dengan tujuan yang lainnya, SMA favorit merupakan tahapan untuk mencapai tujuan selanjutnya yaitu melanjutkan ke perguruan tinggi. Tujuan hidup disampaikan secara tegas oleh siswa dengan menuliskan jurusan dan nama perguruan tinggi yang dituju. Tujuan melanjutkan ke perguruan tinggi memberikan arah terhadap apa yang dilakukan siswa yaitu memilih SMA favorit dengan alasan ingin melanjutkan pendidikan ke perguruan tinggi. Peningkatan kompetensi diri merupakan bekal untuk mendapatkan pengakuan dalam dunia kerja sehingga dapat meningkatkan ekonomi keluarga dan dapat membantu mengubah kemiskinan keluarganya.

Menilik keberadaan subjek sebagai siswa pada SMA favorit terdapat variasi proses yang sama dengan kehidupannya untuk mendapatkan makna hidup. Pengalaman ditinggal oleh kedua orang tua atau ayahnya dan kedua orang tuanya yang merantau merupakan situasi yang menstimulasi siswa dari keluarga miskin dalam mencari makna hidup. Peristiwaperistiwa yang dialami subjek dalam situasi penuh tantangan dan hambatan mengantarkan mereka untuk memperkuat pencarian makna hidup. Penuturan INK dan DNPP tentang penetapan tujuan hidup untuk melanjutkan pendidikan tinggi ke luar negeri dilalui dalam tahapan untuk memenuhi keinginan menebus kegagalan usaha orang tuanya. Keinginan yang kuat untuk menjadi peneliti biokimia dan dokter di rumah sakit menjadikan beberapa subjek istiqomah dan rela kurang tidur setiap harinya. Sikap dan tindakan ditunjukkan oleh RFT yang berusaha keras memberikan pengertian dan keyakinan kepada orang tuanya yang melarang untuk melanjutkan pendidikannya.

Makna hidup dalam dimensi nilai diindikasikan oleh perasaan berharga dan penting karena diberikan kesempatan untuk mengikuti lomba serta memenangkannya. Makna hidup bagi siswa dari keluarga miskin di Wonosobo terdiri dari makna riil dan makna konseptual. Makna riil berkaitan dengan makna yang dialami langsung dan makna konseptual berkaitan dengan pemahaman pengalaman hidup terhadap situasi dan kondisi yang dialami. Makna hidup riil dibedakan menjadi tiga kelompok yaitu makna hidup berawal dari kehampaan, makna hidup berawal dari konflik, dan makna hidup berawal dari makna hidup.

Tujuan yang telah dicapai beserta kegiatan yang terarah untuk mencapai pendidikan tinggi serta nilai yang telah dirasakan merupakan makna konseptual. Makna riil dan konseptual tidak dapat terpisahkan sebab jika makna hanya dibatasi yang riil maka tidak akan ada unsur tujuan yang akan datang yang telah tercapai. Makna hidup konseptual dalam penelitian ini dibatasi pada makna-makna lain yang ditemukan dalam penelitian selain yang diuraikan di atas. Makna terkait dengan situasi khusus dalam kehidupan (Frankl dalam Fridayanti, 2013) sehingga makna hidup riil dan konseptual merupakan pemahaman, tujuan, dan nilai yang berkaitan dengan situasi khusus. Situasi khusus ditunjukkan pada siswa dari keluarga miskin dan hidup dalam lingkungan dengan minat pendidikan rendah, tetapi berkeinginan kuat untuk mendapatkan pendidikan tinggi. Indikasi situasi khusus keluarga miskin adalah kekurangan biaya personal pendidikan setiap tahun yang dalam penelitian ini mencapai rata-rata $57.38 \%$, dengan terendah $13.06 \%$, dan tertinggi $73.22 \%$. Indikasi situasi khusus minat pendidikan masyarakat adalah persentase anak usia 1518 tahun yang sekolah pada pendidikan menengah terhadap penduduk Kabupaten Wonosobo, baru mencapai $38.27 \%$ (BPS, 2016). Makna hidup riil diperoleh siswa miskin yang mampu mencapai SMA favorit dibalik situasi kemiskinan dan rendahnya minat bersekolah. Makna hidup tersebut ditunjukkan dari tiga hal yaitu pemahaman, keinginan dan nilai mengenai SMA favorit. 
Pemahaman, keinginan dan nilai merupakan dimensi makna dalam hidup yang di dalamnya memuat unsur koherensi, tujuan dan signifikansi (Martela \& Steger, 2016).

Dimensi makna hidup yang bersifat konseptual berupa representasi intelektual yang lebih abstrak dari kehidupan yang dijalani oleh para siswa atau pikiran serta ide para siswa dalam konteks makna hidup. Makna hidup konseptual terbagi menjadi dua yaitu berdasarkan kompleksitas dan ketegasan. Makna hidup dalam bahasan ini merupakan konsep makna hidup konseptual yang dapat ditinjau dalam dimensi pemahaman, tujuan, dan nilai (Martela \& Steger, 2016).

Temuan data dalam konteks makna hidup konseptual untuk dimensi koherensi antara lain berkaitan dengan pola hubungan dan prediktabilitas, yaitu pemahaman kondisi keluarga dan takdir yang dapat diubah serta remaja yang tidak bersekolah yang berimplikasi pada perilaku negatif. Dalam dimensi koherensi makna hidup berproses dengan kesadaran untuk perubahan (Steger, Hicks, Krueger, \& Bouchard, 2011). Pemikiran bahwa anak perempuan tidak bersekolah yang tinggi atau kehidupan diukur dengan materi membuat pencarian makna hidup siswa yang berada pada usia remaja. Selain itu ditemukan hal yang tidak selaras dengan persepsinya atau sesuatu yang dianggap tidak masuk akal, yaitu pemikiran anak perempuan tidak boleh sekolah tinggi dan pandangan bahwa hidup mengandalkan uang. Tanpa konsep, tidak akan ada kehendak bermakna untuk melakukan perubahan yang sesuai konsep itu, sedangkan hal yang tidak masuk akal menimbulkan keinginan untuk membuktikan bahwa dirinya yang bermakna itu yang lebih masuk akal. Makna perubahan sesuai konsep Luhmann bahwa perubahan merupakan makna (Rizte, 2014). Pemahaman yang menyadarkan diri (self insight) merupakan awal penemuan makna (Bastaman, 2007).
Temuan lain yang mendukung konsep makna dimensi koherensi terutama berkaitan dengan pola hidup yang dapat dimengerti sebagai keutuhan (Martela \& Steger, 2016). Koherensi ditunjukkan oleh adanya keterhubungan kehidupan dunia dan akhirat; pilihan saat ini, perubahan diri dan masa depan; mengetahui hubungan kesulitan, tuntutan kerja keras, dan harapan; menghubungkan kepandaian yang akan memudahkan memperoleh kebaikan; memperkirakan akibat terjadinya beban yang lebih berat jika salah menentukan pilihan; memperkirakan solusi kendala biaya pendidikan; dan pemahaman adanya kesempatan dibalik kemiskinannya.

Konsep makna hidup dimensi tujuan yang akan mengarahkan pada kegiatan adalah apa yang direncanakan pada masa yang akan datang setelah lulus SMA, atau lebih jauh lagi setelah menyelesaikan pendidikan perguruan tinggi. Makna menarik yang ditemukan dalam kaitan ini adalah: (1) konsep tujuan yang linier dengan latar belakang keluarga yaitu bekerja paruh waktu sambil kuliah; (2) konsep tujuan yang spesifik berpusat pada kebahagiaan orang tuanya seperti menabung dari hasil usaha sendiri untuk orang tua berhaji, dan membangun tempat tinggal untuk orang tua; (3) konsep tujuan untuk melanjutkan pendidikan di Oxford University; (4) konsep tujuan yang detail yaitu melakukan penelitian, usia menikah dan rentang mengasuh anak; (5) konsep tujuan yang terikat dengan sejarah kegagalan orang tuanya. Pengalaman beternak orang tua dijadikan pemicu semangat menutup kegagalan orang tua dengan menulis buku tentang peternakan yang sukses. Martela dan Steger (2016) menyebutkan bahwa tujuan berkaitan dengan motivasi, yaitu keharusan menanggung konsekuensi memilih melanjutkan pendidikan.

Makna hidup konseptual yang berkaitan dengan dimensi nilai sulit ditemukan sebab nilai menurut Martela dan Steger (2016) bersifat lebih kekinian. 
Makna nilai tidak perlu dalam bentuk temporalitas tertentu namun dapat ditemukan signifikansi dari tujuan masa depan, pengalaman masa lalu, dan masa sekarang. Nilai konseptual dapat didasarkan pada hal yang sifatnya evaluatif, misalnya menilai kekurangan ekonomi keluarga akan menyebabkan dirinya lebih mandiri. Kemalasan merupakan ketidakberhasilan dalam menggapai cita-cita, maka kemampuan evaluasi subjek inilah yang menggambarkan makna hidup terutama dalam dimensi nilai atau signifikansi.

Proses pencarian makna hidup siswa miskin dapat dijelaskan menggunakan teknik penemuan makna yang dikembangkan Bastaman (2007) dari Logo analisis Crumbaugh. Pemahaman diri yang sejalan dengan self evaluating, bertindak positif sejalan dengan acting as it, pengakraban hubungan sejalan establishing personal encounter, pendalaman nilai sejalan exploring human values for personal meaning, dan ibadah sejalan establishing with higher being. Pencarian makna menurut Crumbaugh (dalam Bastaman, 2007) diawali dengan self evaluation atau pemahaman diri.

Pemahaman diri awal ditunjukkan oleh ungkapan perasaan terhadap situasi yang membawa derita, yaitu cerita kebangkrutan usaha orang tuanya, ungkapan kesedihan saat ayahnya meninggal dan ungkapan perasaan karena ditinggal orang tuanya merantau. Pemahaman diri berikutnya adalah kesadaran mengenai kekurangan yang dapat dikaitkan dengan penerimaan diri, meliputi ungkapan mengenai keberatan orang tua terhadap kelanjutan pendidikannya dan pemahaman perbandingan besaran pendapatan dan pengeluaran. Kesadaran diri meningkat dengan pemahaman adanya potensi internal yang ditunjukkan yaitu kekurangan keluarga menjadikan lebih mandiri dan kemampuan dalam mengelola dan menghargai uang (hemat), optimis karena memiliki potensi diri dengan diterimanya sebagai siswa di SMA favorit. Kesadaran diri meningkat juga dengan pemahaman potensi eksternal, yang ditunjukkan adanya pemahaman terhadap kesempatan memperoleh fasilitas beasiswa pendidikan.

Tahap bertindak positif sejalan dengan acting as it yang ditunjukkan dengan perilaku dan tindakan nyata yang bermanfaat (Bastaman, 2007). Pemikiran positif diawali oleh kesadaran akan potensi positif bahwa kondisi keluarga merupakan takdir yang dapat diubah. Perubahan dilakukan dengan menjadikan kesempatan untuk bertindak banyak hal dibalik kemiskinannya. Pemikiran positif berlanjut dengan tindakan positif, yaitu meyakinkan orang tua, melakukan hal yang dapat menghemat pengeluaran serta mengarahkan kegiatan untuk mencapai tujuan serta penetapan tujuan-tujuan untuk masa depannya. Tahap pengakraban hubungan sejalan establishing personal encounter dalam upaya untuk mendapat dukungan sosial (social support) terutama dari keluarga, guru dan teman. Dukungan pendidikan yang diberikan berupa pemberian fasilitasi, diskusi pemilihan jurusan perguruan tinggi, apresiasi prestasi, memberikan informasi beasiswa dan pengakuan dari komunitas sekolah. Tahap keempat adalah pendalaman nilai sejalan exploring human values for personal meaning. Bastaman (2007) menyebutkan pendalaman ini dengan catur nilai. Tahap ini merupakan tahap lanjutan dari sebelumnya yang ditunjukkan oleh kesungguhan dalam mengikuti kegiatan dan menyelesaikan tugas-tugas sekolahnya, misalnya bercocok tanam kunyit.

Faktor eksternal lebih mempengaruhi pembelajaran makna hidup siswa miskin seperti pengalaman guru dari keluarga miskin, membaca novel Laskar Pelangi karya Andrea Hirata, nasehat dalam materi kajian Islam di sekolah dan kajian kitab seperti Al Hikam karya Ibnu Athoillah asSakandari serta materi kegiatan kepanduan yang diikuti beberapa subjek. Faktor-faktor ini menginspirasi siswa untuk tetap 
semangat dan bangkit dari keterpurukan ekonomi keluarga.

Makna hidup capaian siswa dari keluarga miskin berimplikasi terhadap kepribadian baik personal maupun sosial. Implikasi personal berupa keseimbangan antara harapan dan rasa syukur atas kondisi keluarganya yang ditunjukkan dengan adanya harapan kuat dan aktivitas terarah untuk dapat meninggalkan kemiskinan. Bersamaan dengan itu subjek menerima kondisi dan mensyukuri bahwa kondisinya menjadi penyebab dirinya lebih mandiri. Implikasi personal ini menjadikan dirinya bangkit dari kemiskinannya dan menjadi lebih superior dari keadaan saat ini (Adler dalam Calvin \& Gardener, 1993) yang menjauhkan dirinya dari depresi (WilchekAviad \& Malka, 2016).

Implikasi sosial ditunjukkan dengan adanya keseimbangan kasih sayang subjek kepada orang tuanya dan kebermanfaatan bagi orang lain. Kasih sayang ditunjukkan dengan keinginan membahagiakan orang tua seperti keinginan membuatkan rumah dan memberangkatkan haji orang tuanya. Kebermanfaatan kepada orang lain ditunjukkan dengan ungkapan keinginan mengubah keadaan dari 'tangan di bawah menjadi tangan di atas'. Keseimbangan harapan dan rasa syukur serta cinta dan kecerdasan sosial menunjukkan pertanda makna hidup yang tinggi. Implikasi sosial makna hidup yang ditunjukkan menjadi lebih bermanfaat, menginspirasi, mewariskan nilai, dan lebih eksis mengandung arti sebagai manifestasi spiritualitas dalam hubungan sosial (Pasiak, 2012).

Keyakinan akan makna dan tujuan hidup juga secara teoretis dan empiris terkait dengan keyakinan bahwa seseorang itu layak (harga diri), orang yang mampu (self-efficacy), serta orang yang memberikan rasa keamanan.

\section{Simpulan}

Konsep makna hidup pada siswa dari keluarga miskin terbagi ke dalam makna hidup riil dan abstrak atau konseptual. Makna hidup riil merupakan makna yang mencakup pengalaman riil yang meliputi dimensi pengetahuan, tujuan dan nilai. Makna hidup konseptual merupakan makna yang direpresentasikan secara abstrak yang belum disertai oleh pengalaman riil terutama dalam dua hal yaitu: tujuan yang belum tercapai, dan nilai bersifat abstrak berupa perasaan yang belum dialami langsung. Makna hidup riil menjadikan siswa dari keluarga miskin di Wonosobo selalu kuat dan tetap semangat menjalani makna hidup abstrak. Pencarian makna hidup dengan pilihan SMA favorit memungkinkan pencapaian dan manfaat menjalani makna hidup abstraknya, yaitu menggapai masa depannya.

Konsep makna hidup siswa bermetamorfosis menjadi konsep baru yang berbeda dari kondisi dan situasi awal keluarga. Siswa memiliki pemikiran komprehensif yang menghubungkan masa kini dan akan datang. Proses pencarian makna hidup berlangsung setelah melewati masa penderitaan dengan pemahaman dan penerimaan diri, berpikir dan bertindak positif hingga mendapatkan pengakuan atau nilai. Hasil pencarian makna hidup berimplikasi terhadap aspek personal dan sosial siswa miskin yang menyeimbangkan antara harapan dan perasaan syukur yang berkaitan dengan kondisi kemiskinanya dan termanifestasi untuk mengubah citra dirinya dari seorang penerima menjadi pemberi.

\section{Daftar Pustaka}

Bastaman, H. D. (1995). Integrasi psikologi dengan Islam mепији psikologi Islam. Yogyakarta: Kerja Sama Antara Yayasan Insan Kamil \& Pustaka Pelajar.

Bastaman, H. D. (2007). Logoterapi: Psikologi untuk menemukan makna hidup dan meraih hidup bermakna. Jakarta: PT Raja Grafindo Persada.

Baumeister, R. F. (1991). Meaning of life. New York: Guildford Press. 
Berti, C., \& Pivetti, M. (2017). Childhood economic disadvantage and antisocial behavior: Intervening factors and pathways. Children and Youth Services Review. doi:10.1016/j.childyouth.2017.06.007

Calvin, S. H., \& Lindzey, G. (1993). Psikologi kepribadian 2, Teori-teori psikodinamika. Yogyakarta: Kanisius.

Cheung, C., \& Chou, K. (2016). Working poor in Hong Kong. Social Indicators Research, 129(1), 317-335.

Crarke, M., \& Feeny, S. (2007). Education for the end of poverty: Three ways forward. New York: Nova Science Publisher Inc.

Frankl, V. E. (2006). Logoterapi terapi psikologi melalui pemaknaan eksistensi, terj. M. Murtadho. Jogjakarta: Kreasi Wacana.

Fridayanti. (2013). Pemaknaan hidup (Meaning in life) dalam kajian psikologi. Psikologika, 18(2), 189-198.

George, L. S., \& Park, C. L. (2014). Existential mattering: Bringing attention to a neglected but central aspect of meaning?. Dalam A. Batthyany \& P. Russo-Netzer (Eds.), Meaning in positive and existential psychology, New York: Springer.

George, L. S., \& Park, C. L. (2013). Are meaning and purpose distinct? An examination of correlates and predictors. The Journal of Positive Psychology, 8(5), 365-375.

Heintzelman, S. J., \& King, L. A. (2014). The Feeling of Meaning-asInformation. Personality and Social Psychology Review, 18(2), 153-167.

Kashdan, T. B., \& McKnight, P. E. (2013). Commitment to a purpose in life: An antidote to thesuffering by individuals with social anxiety disorder. Emotion, 13(6), 1150-1159.

Liputo, S. (2014). Distres psikologik dan disfungsi sosial ditemukan pada kalangan masyarakat miskin Kota Malang, Jurnal Sains dan Praktik Psikologi, 2(3), 286-295.
Martela, F., \& Steger, M. F.. (2012). Experiencing meaning in life - Optimal functioning at the nexus of wellbeing, psychopathology, and spirituality. Dalam T. P. Wong (Ed.). The human quest for meaning theories, research, and applications. New York: Routledge.

Martela, F., \& Steger, M. F. (2016) The three meanings of meaning in life: Distinguishing coherence, purpose, and significance. The Journal of Positive Psychology, 11(5), 531-545, doi: 10.1080/17439760.2015.1137623

Martono, N. (2017). Sekolah publik vs sekolah privat: Dalam wacana kekuasaan, demokrasi dan liberasi pendidikan, (hlm. 82). Jakarta: Yayasan Pustaka Obor Indonesia.

Mcknight, P. E., \& Kashdan, T. B. (2009). Purpose in life as a system that creates and sustains health and well-being: An integrative, testable theory. Review of General Psychology, 13(3), 242-251.

Mustea, A. (2012). Nowadays' teenagers and the meaning of life. Colegiul National "Moise Nicoara" Arad fondat in 1873-, (2). "Vasile Goldis" Western University, Arad.

Nasir, M. (2016). Laporan tahunan. Kementerian Riset Teknologi dan Pendidikan Tinggi.

Noviawati, P., \& Undarwati, A. (2017). Gambaran dinamika kemiskinan ditinjau dari atribut psikologis: Studi pada masyarakat miskin di Kota Semarang. Prosiding Seminar Nasional Multi Disiplin Ilmu \& Call For Papers Unisbank Ke-3 (Sendi_U 3). Park, C. L., \& George, L. S. (2013). Assessing meaning and meaning making in the context of stressful life events: Measurement tools and approaches. The Journal of Positive Psychology, 8(6), 483-504. http://dx.doi.org/10.1080/17439760.20 13.830762 .

Pasiak, T. (2012). Tuhan dalam otak manusia. Bandung: Mizan. 
Purwanda, O. B. (2015). Kebermaknaan hidup pada remaja yang mengalami putus sekolah (Tesis tidak diterbitkan). Unissula, Fakultas Psikologi.

Rashid, A., \& Samat, N. (2018). Kemiskinan keluarga dan pengaruhnya terhadap tahap pendidikan rendah masyarakat luar bandar: Kajian kasus di jajahan Bachok, Kelantan (Family poverty and its influence on rural community low education: Case study in Bachok District, Kelantan). $E$ Bangi, 15(2), 11-23.

Noviawati, P., \& Narendri, N. (2017). Nilai-nilai kemiskinan pada masyarakat miskin di daerah perkotaan dan pedesaan: Ditinjau berdasarkan analisis atribut psikologis. Prosiding Industrial Research Workshop and National Seminar. Politeknik Negeri Bandung July 26-27.

Ratcliffe, C. (2015). Child poverty adult success. Urban Institute.

Rizte, G. (2014). Teori sosiologi modern, (hlm. 236). Jakarta: Prenada Media.

Sari, N. M., \& Purwaningsih, I. E. (2012). Hubungan kebermaknaan hidup dengan penerimaan diri pada kaum waria di Yogyakarta, Jurnal Spirits, 3(1), 76-84.
Sasmal, J., \& Guillen, J. (2015). Poverty, educational failure and the child-labour trap: The Indian experience. Global Business Review, 16(2), 270-280. doi;1177/0972150914564419.

Steger, M. F., Hicks, B. M., Krueger, R. F., \& Bouchard, T. J. (2011). Genetic and environmental influences and covariance among meaning in life, religiousness, and spirituality. The Journal of Positive Psychology, 6(3), 181-191.

Wilchek-Aviad, Y. \& Malka, M. (2016). Religiosity, meaning in life and suicidal tendency among jews. Journal of Religion and Health, 55(2), 480494.

Woessmann, L. (2015). The economic case for education. Education Economics, 24(1), 3-32. doi:10.1080/09645292.2015.10598

O’Neal, C. W., Arnold, A. L., LucierGreer, M., \& Wickrama, K. A. S. (2015). Economic pressure and health and weight management behaviors in African American couples: A family stress perspective. Journal of Health Psychology, 20(5) 625-637. DOI: $10.1177 / 1359105315579797$. 
Psympathic, Jurnal Ilmiah Psikologi Juni 2019, Vol. 6, No. 1, Hal. : 85-98 